\title{
Productive and Reproductive Performances of New Zealand White Doe Rabbits as Affected by Nigella Sativa Oil Supplementation under Hot and Mild Conditions in Egypt \\ Abd El-Monem, U.M.*, B.A. Khalil* and M.A.M. Abdel-Hafez** \\ * Department of Animal Production, Faculty of Agriculture, Zagazig University, Zagazig, Egypt. \\ **Animal Production Research Institute, Agric. Res. Center, Ministry of Agriculture, Egypt.
}

\begin{abstract}
Aim of the current study was to evaluate the effect of nigella sativa oil (NSO) supplementation under hot and mild Egyptian conditions, on physiological thermoregulatory response, blood components, gestation length, feed and water consumption during gestation and suckling period, litter size and weight at each of birth, $21 \mathrm{~d}$ and $30 \mathrm{~d}$ (weaning) of age and mortality rate of pups from birth to 30 days of age. Thirty New Zealand White (NZW) adult doe rabbits (15 in hot season and 15 in mild season) aged 6 months and weighed $2935.4 \mathrm{~g}$ were used. Results showed that feed intake, water consumption, rectal temperature, respiration rate, litter size and weight at birth, $21 \mathrm{~d}$, weaning, pre-weaning mortality rate were affected significantly $(\mathrm{P}<0.01)$, while the gestation period, serum total proteins, albumin, globulin, urea and creatinine were not affected significantly by season. Supplementation the doe rabbits diet with NSO (30 g oil / kg diet) significantly improved litter size and weight at birth $(\mathrm{P}<0.01$ and $\mathrm{P}<0.05)$, at $21 \mathrm{~d}$ and at weaning $(\mathrm{P}<0.05)$, while pre-weaning mortality rate, gestation period, feed intake, water intake, rectal temperature, respiration rate, serum total protein, albumin, globulin, urea and creatinine concentrations in blood plasma of does were not affected.It could be concluded that, feeding doe rabbits during the hot season with dietary supplementation of $30 \mathrm{~g}$ Nigella sativa oil $/ \mathrm{kg}$ diet is very effective on productive and reproductive performances of rabbits.
\end{abstract}

Keywords: Rabbit, Nigella sativa, reproduction, blood biochemicals.

\section{INTRODUCTION}

There are many factors affecting the economic intensive rabbit production such as environmental and nutritional conditions. The environmental condition plays important elements in production cycle. The domestic rabbits are homoeothermic mammals. It has a high metabolic rate under developed sweat glands and slow heat loss. The thermo neutral zone of growing rabbits (6-12 weeks of age) is $15-18{ }^{\circ} \mathrm{C}$ (Marai and Habeeb, 1994; Habeeb et al., 1998). The high temperature in hot climate conditions affects negatively growth reproductive performance and feed intake (Marai et al., 1999, 2000, 2006; Abdel-Monem, 2012).

Nigella sativa (NS) oil (NSO) and meal (NSM) are becoming commonly used for many purposes, as feed additives and for medical purposes. The NS is well known for its antibacterial, antifungal, antihelminthic, antineoplastic bronchodilator immune enhancing and antispasmodic effects (Rathee et al., 1982; Mahdi, 1993; Khodary et al., 1996).

NSO is considered good source of each of fat and the major minerals such as $\mathrm{Ca}, \mathrm{P}, \mathrm{K}, \mathrm{Mg}$ and $\mathrm{Na}$ (Abdel-Aal and Attia, 1993). The unsaturated fatty acids, oleic and linoleic, as two major fatty acids are extracted from the black seed oil (Abdel-Aal and Attia, 1993).

The present study was conducted to investigate the effects of Nigella sativa oil supplementation on reproductive performance of adult NZW doe rabbits in hot and mild conditions in Egypt.

\section{MATERIALS AND METHODS}

This study was carried out at a Rabbit Farm, Faculty of Agriculture, Zagazig University during the period from July, 2015 to May, 2016.
Factorial design was conducted to study the effects of season (hot and mild), with or without NSO supplementation on productive and reproductive performances of New Zealand White doe rabbits during hot season from June to September, 2015 and mild climate period from October, 2015 to May, 2016.

Total number of 30 NZW does aged 6 months and weighed $2935.4 \mathrm{~g}, 15$ does in hot season and 15 does in mild season were used in this study. During each season, does were randomly divided into three groups ( 5 does in each group).

Average of ambient temperature and relative humidity at midday inside building of rabbits during the experimental period were $20.31^{\circ} \mathrm{C}$ and $73.6 \%$ in the mild season and $28.13^{\circ} \mathrm{C}$ and $79.5 \%$ in the hot season, respectively.

Doe rabbits in all groups were fed a basal diet, but differed in dietary supplementation of NSO. Does in the $1^{\text {st }}$ group (G1) were fed the basal diet without NSO and served as control group, while those in the $2^{\text {nd }}$ (G2) and $3^{\text {rd }}(\mathrm{G} 3)$ groups were fed the basal diet supplemented with 15 and $30 \mathrm{~g} \mathrm{NSO} / \mathrm{kg}$ diet, respectively.

Rabbits were fed ad libitum basal diet consisting of $28 \%$ alfalfa hay, $18 \%$ barley, $18 \%$ soybean meal (44\% CP), 25\% wheat bran, 6\% yellow corn, 3\% molasses, $1.1 \%$ limestone, $0.3 \%$ sodium chloride, $0.6 \%$ vitamin and mineral premix. The basal diet contained $18.18 \%$ crude protein, $13.43 \%$ crude fiber, $2.29 \%$ ether extract and $2656.00 \mathrm{kcal}$ digestible energy $/ \mathrm{kg}$ diet. All rabbits were kept under the same managerial, hygienic and environmental conditions. Does were individually reared in wire cages and their offsprings were collectively raised in cages, in the same batteries, in a well-ventilated building. Fresh water was automatically available all the time by stainless steel nipples fixed in each cages. All doe cages were equipped with feeders 
and nipples. During the experiment the total artificial light was about 16 hours/day. At mating, rabbits were individually transferred to the buck cages and returned to their own hatches copulation. Each mated doe was palpated 10 days post-mating to be rebred until pregnancy was established. Within 12 hours after kindling, litter kits were recorded and weaned at 30 days of age.

The traits studied for does included gestation length, feed and water consumption during gestation and suckling period, litter size and weight at each of birth, 21 and 30 days (weaning) of age, litter weight gain and mortality rate of pups from birth to 30 days of age.

$\mathrm{Y}=$ litter weight gain $(\mathrm{kg})$ during the period from 0 to 21 days $/ 0.56$.

Where: 0.56 was standard figure given by Cowie

(1969) for the NZW strain depending on the linear relationship between the litter weight gain $(\mathrm{kg})$ and doe milk consumed.

Rectal temperature (RT) and respiration rate (RR) were measured in does once every two weeks at 12 p.m. RR was recorded by a hand counter, which counts the frequency of the flank movement per minute. Internal body temperature (RT) was taken by medicine thermometer inserted into the rectum for 2 minutes at depth of one $\mathrm{cm}$.

Blood samples were monthly collected from the marginal ear vein of does after shaving and cleaning with alcohol in less than 2 minutes into dry clean centrifuge tubes containing some drops of heparin. Blood plasma was separated by centrifugation at 3000 rpm for 20 minutes and kept in a deep freezer at $-20^{\circ} \mathrm{C}$ until the time of analysis. Total proteins, albumin, creatinine and urea concentrations in plasma were estimated using commercial kits (Bio Merieux, France) according to the procedure outlined by the manufacturer. Globulin concentration was obtained by subtracting the values of albumin from the corresponding values of total proteins.

In order to study the combined effects of temperature and humidity, temperature humidity index (THI) was calculated according to the formula of Marai et al. (2001) as follows:

$$
\mathrm{THI}=\mathrm{db} \mathrm{C}^{o}-\left\{(0.31-0.31 \mathrm{RH})\left(\mathrm{db} \mathrm{C}^{o}-14\right)\right\}
$$

Where: $\mathrm{db}{ }^{\circ} \mathrm{C}=$ dry bulb temperature in Celsius and $\mathrm{RH}=$ relative humidity $/ 100$. The estimated values of THI were classified as follows: $<22.2=$ absence of heat stress, 22.2- $<23.2=$ moderate heat stress, $23.3-<25.5=$ severe heat stress and $\geq 25.5=$ very severe heat stress. Data obtained from all does and their litters (offsprings) during hot and mild seasons were subjected to the statistical analysis using factorial design (2 seasons x 3 NSO levels) according to Snedecor and Cochran (1982) by the following model: $\mathrm{X}_{i j k l}=\mu+\mathrm{P}_{\mathrm{i}}$ $+\mathrm{N}_{k}+\mathrm{PN}_{i k}+\mathrm{E}_{i k l}$.

where: $\mu=$ general mean, $\mathrm{P}_{i}=$ fixed effect of season (1, $2), \mathrm{N}_{k}=$ fixed effect of NSO level $(1, \ldots .3), \mathrm{PN}_{i k}=$ the interaction between season and NSO, and $\mathrm{E}_{i k l}=$ random error. The significant differences among means were tested by Duncan's multiple range test (Duncan, 1955).

\section{RESULTS AND DISCUSSION}

\section{Temperature-humidity index (THI):}

Estimated THI values were 18.9 and 24.7 at mild and hot seasons, respectively. These results indicated absence of heat stress during the mild season (less than 22.2) and exposure to severe heat stress during the hot season (23.3-25.5). Marai et al. (1996) found that NZW does were under severe heat stress during the summer season in Egypt.

\section{Feed intake and water consumption:}

Feed intake which includes feed consumption significantly $(\mathrm{P}<0.01)$ decreased in hot compared with mild season (Table 1). This means that feed intake of does was affected by season. This may be explained on the basis that rabbits required more dietary energy during cold conditions, which was covered by increasing feed consumption. Conversely, rabbits which exposed to sever heat stress increases heat production, so the voluntary feed intake decreased. These results agreed with this obtained by Abdel-Monem (2000), Ayyat and Abdel-Monem (2002), and Marai et al. (2000, 2002, 2006), who stated that feed intake was decreased significantly in doe NZW rabbits under heat stress condition. Generally, feed intake covered rabbit requirements according to NRC (1977). The present results indicated that both NSO levels supplementation significantly $(\mathrm{P}<0.05)$ increased feed intake of does in G2 and G3 as compared to control group (Table 1).

Average water consumption showed an opposite trend to that of feed intake during both seasons. Water consumption was significantly $(\mathrm{P}<0.01)$ higher in hot than in mild season (Table 1). These results agreed with Abdel-Monem (2000), who found that water intake was increased significantly $(\mathrm{p}<0.01)$ in doe NZW rabbits under heat stress condition. However, both NSO levels supplementation insignificantly increased water consumption as compared to control shown in table 1 .

The effect of interaction between season and NSO supplementation was not significant on feed intake and water consumption ((Table 1).

Table 1. Feed intake and water consumption of New Zealand White doe rabbits as affected by season of the year, dietary supplementation with Nigella sativa oil and their interaction.

\begin{tabular}{ccc}
\hline Item & $\begin{array}{c}\text { Feed intake } \\
(\mathrm{g} / \text { day })\end{array}$ & $\begin{array}{c}\text { Water } \\
\text { consumption } \\
(\mathrm{ml} / \mathrm{day})\end{array}$ \\
\hline
\end{tabular}

\section{Season (s):}

Hot

Mild

Significance

$200.4 \pm 3.1^{\mathrm{b}}$

$500.3 \pm 11.7^{\text {a }}$

Nigella sativa oil level :

Without Nigella sativa oil

$15 \mathrm{~g}$ oil / $\mathrm{kg}$ diet

$30 \mathrm{~g}$ oil $/ \mathrm{kg}$ diet

Significance

Interaction: $\mathrm{S} \times \mathrm{N}$

$296.9 \pm 1.7$

$287.5 \pm 6.4^{\mathrm{b}}$

Means bearing different letters in the same column within each classification differ significantly at $\mathbf{P}<0.05(*)$ and $\mathbf{P}<0.01(* *)$. NS: Not significant. 


\section{Physiological response:}

Physiological response of doe rabbits was in terms of rectal temperature (RT) and respiration rate $(\mathrm{RR})$. Hot climatic $(\mathrm{THI}=24.7)$ showed significantly $(\mathrm{p}<0.01)$ higher values of RT and RR than mild conditions $(\mathrm{THI}=18.9)$. These results may be due to exposure of rabbits to heat stress. These results agreed with those obtained by Ayyat and Abdel-Monem (2002), Marai et al. (2000, 2002, 2006) and AbdelMonem (2015), who found that RT and RR of rabbits were significantly $(p<0.05)$ higher in summer than in winter under Egyptian conditions. Both RT and RR were not affected significantly by NSO supplementation. These results agreed with Marai et al. (2009), Shewita and Taha (2011) and Rizwana et al. (2013), who found that RT and RR were not affected by Nigella sativa supplementation.

It is of interest to note that the effect of interaction between season and NSO supplementation was not significant on RT and RR (Table 2).

\section{Blood constituents:}

Results in Table 3 showed that all blood constituents studied including concentration of total proteins, albumin, globulin, urea and creatinines were not affected significantly by season, NSO supplementation and their interaction. The present results agreed with those reported by Ayyat and AbdelMonem (2002) and Marai et al. (2006), Shewita and Taha (2011), Rizwana et al. (2013) and Abdel-Monem (2012)

Table 2. Rectal temperature and respiration rate of New Zealand White doe rabbits as affected by season of the year, dietary supplementation with Nigella sativa oil and their interaction.

\begin{tabular}{lcc}
\hline Item & $\begin{array}{c}\text { Rectal temperature } \\
\left({ }^{\circ} \mathbf{C}\right)\end{array}$ & $\begin{array}{c}\text { Respiration rate } \\
\text { (Resp. /minute) }\end{array}$ \\
\hline Season (S): & $39.7 \pm 0.08^{\mathrm{a}}$ & $136.3 \pm 1.12^{\mathrm{a}}$ \\
Hot & $39.0 \pm 0.03^{\mathrm{b}}$ & $101.9 \pm 0.96^{\mathrm{b}}$ \\
Mild & $* *$ & \\
Significance & & \\
Nigella sativa oil level : & $39.36 \pm 0.09$ & $116.53 \pm 1.09$ \\
Without Nigella sativa oil & $39.39 \pm 0.06$ & $114.68 \pm 1.11$ \\
15 g oil / kg diet & $39.41 \pm 0.09$ & $118.21 \pm 1.17$ \\
30 g oil / kg diet & $\mathrm{NS}$ & $\mathrm{NS}$ \\
Significance & $\mathrm{NS}$ & $\mathrm{NS}$ \\
Interaction: S x N & &
\end{tabular}

Means bearing different letters in the same column within each classification differ significantly at $\mathrm{P}<0.01 \quad(* *)$. NS: Not significant.

Table 3. Concentration of some biochemicals in blood plasma of New Zealand White doe rabbits as affected by season of the year, dietary supplementation with Nigella sativa oil and their interaction.

\begin{tabular}{|c|c|c|c|c|c|}
\hline Item & $\begin{array}{c}\text { Total proteins } \\
(\mathrm{g} / \mathrm{dl})\end{array}$ & $\begin{array}{l}\text { Albumin } \\
(\mathrm{g} / \mathrm{dl})\end{array}$ & $\begin{array}{l}\text { Globulin } \\
(\mathrm{g} / \mathrm{dl})\end{array}$ & $\begin{array}{c}\text { Urea } \\
(\mathrm{mg} / \mathrm{dl})\end{array}$ & $\begin{array}{c}\text { Creatinine } \\
(\mathrm{mg} / \mathrm{dl})\end{array}$ \\
\hline \multicolumn{6}{|l|}{ Season (S) } \\
\hline Hot & 6. $3 \pm 0.4$ & $3.4 \pm 0.12$ & $2.9 \pm 0.46$ & $15.6 \pm 0.09$ & $1.10 \pm 0.07$ \\
\hline Mild & $6.5 \pm 0.3$ & $3.9 \pm 0.15$ & $2.6 \pm 0.33$ & $15.9 \pm 0.07$ & $1.04 \pm 0.02$ \\
\hline Significance & NS & NS & NS & NS & NS \\
\hline \multicolumn{6}{|l|}{ Nigella sativa oil level : } \\
\hline Without Nigella sativa oil & $6.7 \pm 0.4$ & $3.5 \pm 0.20$ & $3.2 \pm 0.29$ & $16.32 \pm 0.05$ & $1.22 \pm 0.16$ \\
\hline $15 \mathrm{~g}$ oil / kg diet & $6.4 \pm 0.5$ & $3.1 \pm 0.24$ & $3.3 \pm 0.31$ & $16.03 \pm 0.08$ & $1.18 \pm 0.30$ \\
\hline $30 \mathrm{~g}$ oil $/ \mathrm{kg}$ diet & $6.8 \pm 0.3$ & $3.4 \pm 0.19$ & $3.4 \pm 0.39$ & $15.11 \pm 0.08$ & $1.20 \pm 0.40$ \\
\hline Significance & NS & NS & NS & NS & NS \\
\hline \multicolumn{6}{|l|}{ Interactions } \\
\hline $\mathrm{S} \times \mathrm{N}$ & NS & NS & NS & NS & NS \\
\hline
\end{tabular}

NS = Not significant.

\section{Productive and reproductive performance}

Data presented in Table (4) showed insignificant

effect due to season on gestation period length. However, litter size at birth, 21 days and weaning was significantly $(\mathrm{P}<0.01)$ higher for kids born in mild than in hot season. In addition, litter weight (Table 5) was significantly $(\mathrm{P}<0.01)$ higher for kits born in mild than in hot season.

Such difference may be a reflection of differences in seasonal climatic conditions. Also, the drop in litter size and weight in hot conditions may be attributed to the effect on mothering ability and milk production as a result of hyperthermia.

Similar trend was obtained by Shafie et al. (1984), Askar (1989), , Hassan et al. (1994), Bassuny (1999), Abdel-Monem (2000), Ayyat and AbdelMonem (2002) and Marai et al. (2000, 2002, 2006). In respect with gestation period, Abd El- Moty et al.
(1991), Shewita and Taha (2011) and Rizwana et al. (2013) reported similar results.

Data presented in Table (4) showed that preweaning mortality rate was significantly $(\mathrm{P}<0.05)$ higher in hot than in mild season. This result may be due to the direct effect of heat stress on the sensitive young offspring in addition to reduction of dam milk production as a result of heat exposure due to the general depression of metabolic activity in such conditions (Shafie et al., 1984). The present results agreed with those obtained by Abdel-Monem (2000), Ayyat and Abdel-Monem (2002) and Marai et al. (2000, 2002, 2006), who found that pre-weaning mortality rate was significantly $(\mathrm{P}<0.05)$ higher in summer than in winter under Egyptian conditions.

Data presented in Tables 4 and 5 showed that addition of NSO to diets of NZW rabbits significantly improved liter size $(\mathrm{P}<0.05)$ and litter weight $(\mathrm{P}<0.01)$ comparatively with control, while gestation period was 
not affected by NSO supplementation. Generally, the supplementation of NSO at a level of $30 \mathrm{~g} / \mathrm{kg}$ diet seemed to be an optimum level owing to the best performance of doe rabbits compared with $15 \mathrm{~g} / \mathrm{kg}$ diet. These results coincide with those of Nasr and Attia
(1998), Shewita and Taha (2011) and Rizwana et al. (2013). On the other side, the interaction effect between season and NSO supplementation was not significant on litter size and litter weight (Tables 4 and 5).

Table 4. Gestation period, litter size and pre-weaning mortality rate of New Zealand White rabbits as affected by season of the year and dietary supplementation with Nigella sativa oil and their interactions.

\begin{tabular}{|c|c|c|c|c|c|}
\hline Item & $\begin{array}{c}\text { Gestation } \\
\text { Period (day) }\end{array}$ & Birth & $\begin{array}{l}\text { Litter size } \\
21 \text { days }\end{array}$ & Weaning & $\begin{array}{c}\begin{array}{c}\text { Pre-weaning mortality } \\
\text { (As number) }\end{array} \\
\end{array}$ \\
\hline \multicolumn{6}{|l|}{ Season (S): } \\
\hline Hot & $31.0 \pm 03$ & $3.8 \pm 0.4^{\mathrm{b}}$ & $2.3 \pm 0.1^{\mathrm{b}}$ & $1.5 \pm 0.4^{\mathrm{b}}$ & $2.3 \pm 0.08^{\mathrm{a}}$ \\
\hline Mild & $31.2 \pm 0.1$ & $5.9 \pm 0.5^{\mathrm{a}}$ & $5.0 \pm 0.2^{\mathrm{a}}$ & $4.7 \pm 0.3^{\mathrm{a}}$ & $1.2 \pm 0.05^{\mathrm{b}}$ \\
\hline Significance & NS & $* *$ & $* * *$ & $* * *$ & $*$ \\
\hline \multicolumn{6}{|c|}{ Nigella sativa oil level: } \\
\hline \multicolumn{6}{|l|}{ Without oil } \\
\hline $15 \mathrm{~g}$ oil $/ \mathrm{kg}$ diet & $31.1 \pm 0.2$ & $4.8 \pm 0.6^{\mathrm{b}}$ & $2.9 \pm 0.3^{b}$ & $2.0 \pm 0.4^{\mathrm{b}}$ & $2.80 \pm 0.11$ \\
\hline $30 \mathrm{~g}$ oil $/ \mathrm{kg}$ diet & $30.9 \pm 03$ & $6.2 \pm 0.8^{\mathrm{a}}$ & $4.8 \pm 0.6^{\mathrm{a}}$ & $4.4 \pm 0.8^{\mathrm{a}}$ & $1.80 \pm 0.14$ \\
\hline Significance & $31.4 \pm 04$ & $6.5 \pm 0.9^{\mathrm{a}}$ & $5.3 \pm 0.4^{\mathrm{a}}$ & $4.9 \pm 0.8^{\mathrm{a}}$ & $1.30 \pm 0.13$ \\
\hline Interaction: & NS & $* *$ & $* *$ & $* *$ & NS \\
\hline $\mathrm{S} \times \mathrm{N}$ & NS & NS & NS & NS & NS \\
\hline
\end{tabular}

Means bearing different letters in the same column within each classification differ significantly at $\mathrm{P}<0.05(*), \mathrm{P}<0.01(* *)$ and $\mathrm{P}<0.001$ $(* * *)$. NS: Not significant.

Table 5. Litter weight (g) of New Zealand White doe rabbits as affected by season of the year and dietary supplementation with Nigella sativa oil and their interaction.

\begin{tabular}{lccc}
\hline \multirow{2}{*}{ Item } & \multicolumn{3}{c}{ Litter weight (g) } \\
& Birth & 21 days & Weaning \\
\hline Season (S): & $44.1 \pm 1.0^{\mathrm{b}}$ & $239.2 \pm 6.9^{\mathrm{b}}$ & $475.7 \pm 18^{\mathrm{b}}$ \\
Hot & $50.8 \pm 0.9^{\mathrm{a}}$ & $318.5 \pm 7.8^{\mathrm{a}}$ & $669.0 \pm 16^{\mathrm{a}}$ \\
Mild & $* *$ & $* * *$ & $* * *$ \\
Significance & & & \\
Nigella sativa oil level: & $46.1 \pm 1.1^{\mathrm{b}}$ & $245.5 \pm 6.3^{\mathrm{b}}$ & $511.7 \pm 13^{\mathrm{b}}$ \\
Without oil & $50.3 \pm 1.6^{\mathrm{a}}$ & $303.0 \pm 8.9^{\mathrm{a}}$ & $605.9 \pm 10^{\mathrm{a}}$ \\
15 g oil / kg diet & $58.4 \pm 1.4^{\mathrm{a}}$ & $319.3 \pm 9.3^{\mathrm{a}}$ & $620.2 \pm 17^{\mathrm{a}}$ \\
30 g oil / kg diet & $*$ & $* *$ & $* *$ \\
Significance & & & \\
Interaction:S x N & $\mathrm{NS}$ & $\mathrm{NS}$ & $\mathrm{NS}$
\end{tabular}

Means bearing different letters in the same column within each classification differ significantly at $\mathbf{P}<0.01(* *)$ and $\mathbf{P}<0.001(* * *)$. NS: Not significant.

\section{CONCLUSION}

It could be concluded that, Nigella sativa oil supplementation to diet of New Zealand White adult doe rabbits increased feed intake and improved litter size and weight from birth to weaning of rabbits kept under hot conditions in Egypt.

\section{REFERENCES}

Abd El-Aal, L. and R. Attia (1993). Characterization of black cumin (Nigella sativa): Chemical composition and lipids. Alex. Sci. Exch., 14 (4): 467-481.

Abdel-Monem, U.M. (2012). Effects of dietary oil supplementation on reproductive performance, blood biochemistry and picture of adult female and male New Zealand White rabbits, Egyptian. J. of rabbit Sci., 4(1): 121-131.

Abdel-Monem, U.M. (2000). Dietary supplementation with ascorbic acid and its effects on productive and reproductive performance of New Zealand white rabbits, under the summer condition of Egypt. Second Inter. Conf. on Animal Pord. \& Health in Semi-Arid Areas. pags: 319-327
Abd El-Moty, A.K.I., A.A. Abd El-Hakeam and M.A.Z. Abd El-Rahman (1991). Physiological responses of rabbits to high air temperature. 2. Productive and reproductive efficiency. Egyptian Journal of Rabbit Science, 1 (2): 146-158.

Askar, A.A.S. (1989). Studies on reproduction of female rabbits. M. Sc. Thesis, Faculty of Agriculture, Zagazig University, Zagazig, Egypt.

Ayyat, M.S. and U.M. Abdel-Monem(2002). Effect of dietary protein level on growing and mature rabbit performance, under summer condition of Egypt. $3^{\text {rd }}$ Sci. Con. on Rabbit Production in Hot Climates, 811 Oct, pp 287-300.

Bassuny, S.M. (1999). Performance of doe rabbits and their weanlings as affected by heat stress and their alleviation by nutritional means under Egyptian condition. Egyptian Journal of Rabbit Science, 9 (I): 73-86.

Cowie, A.T. (1969). Variation in the yield and composition of the milk during lactation in the rabbit and the glactopaietic effect of prolactin. Journal of Endocrinology, 44: 437-450.

Duncan, D.B. (1955). Multiple range and multiple F-test. Biometrics, 11: 1-42.

Habeeb, A.A.M., El-MaghawryA.M., Marail.F.M., GadA.E.(1998): Physiological thermoregulation mechanism in rabbits drinking saline water under hot summer conditions. In: 1st International Conference on versus Acclimatization Rabbits El Arish North Sinai, Egypt, 443-456.

Hassan, N.S.; El-Tawil, E.A.; Shahin Karima, A. and Hatem, A.M.G. (1994). Performance of New Zealand White does as affected by different environmental factors. Proceedings of the first International Conference " Rabbit Production in Hot Climate", Egypt, 1:271-278.

Khodary, R.M., M.H. El-Ezzawy and I.R. Hamdy (1996). Effect of I on egg production, hatchability percentage and some biochemical values in laying hens with reference to fertility in cockerels. $7^{\text {th }}$ Sci., Cong., Fac. Vet. Med., Assuit Univ., 17-19 Nov. 
Mahdy, H.E.A. (1993). Effect of Nigella sativa L on the immune system in cirrhotic patients MD. Thesis in Internal Medicine, Fac. Med., Al-Azhar Univ.

Marai, I.F.M. and Habeeb A.A.M. (1994): Thermoregulation in rabbits. Options Mediterraneennes 8, 33-41.

Marai, I.F.M., M.S. Ayyat, H.A. Gabr and U.M. AbdelMonem (1996). Effect of summer heat stress and its amelioration on production performance of New Zealand White adult female and male rabbits, under Egyptian conditions. $6^{\text {th }}$ World Rabbits Congress, Toulouse, France, 2: 197-208.

Marai , I.F.M., M.S. Ayyat, H.A. Gabr and U.M. AbdelMonem (1999). Growth performance, some blood metabolites and carcass traits of New Zealand White broiler male rabbits as affected by heat stress and its alleviation, under Egyptian condition. Cahiers Option Mediterranean's, 8: 35-42.

Marai, I.F.M., M.S. Ayyat and U.M. Abdel-Monem (2000). Young doe rabbit performance traits as affected by dietary, Zinc, Copper, Calcium or Magnesium, under winter and summer condition of Egypt. Proceeding of the $7^{\text {th }}$ World Rabbit Conference, Spain, 8: $313-320$.

Marai, I.F.M., M.S. Ayyat and U.M. Abdel-Monem (2001). Growth performance and reproductive traits at first parity of New Zealand White female rabbits as affected by heat stress and its alleviation under Egyptian conditions. J. Trop. Animal Health Prod., 33: $1-12$.

Marai, I.F.M., A.A.M Habeeb and A.E. Gad (2002). Rabbits productive, reproductive and physiological performance traits as affected by heat stress: a review. Livestock Production Science, 78: 71-90.

Marai, I.F.M., A.A. Askar and L.B. Bahgat (2006). Tolerance of New Zealand and Californian doe rabbits at first parity to the sub-tropical environment of Egypt. Livestock Production Science, 104: 165172.
Marai, I.F.M., U.M. Abd El-Monem and Kh.M.A. Mahrose (2009). Exotic male rabbit semen traits as affected by feeding systems and dietary supplementation with Nigella Sativa seeds under Egyptian conditions. Egyptian Poultry Science Journal, 28 (III): 833 - 847.

NRC, (1977). Nutrient Requirements of Rabbits National Academy of Science .Washington. 1214 - 1223. Rabbit Sci., 8(2): 95 - 112

Nasr, A.S. andA.I. Attia (1998). Nutritive value of Nigella sativa L. seeds and its effect on rabbit growth and reproductive performance under summer conditions of Egypt. First international conference on animal production and health in semi-arid areas, Arish, Egypt, 1-3 September, 1998, 457-462.

Rathee, P.S., S.H. Mishra and R. Kaushal (1982). Antimicrobial activity of essential oil, fixed oil and unsapanifiable matter of Nigella sativa L. Indian J. Pharmac. Sci., 44: 8-10.

Rizwana, B., S.B. Masood, K.S. Mian and N. Haq (2013). Effect of Nigella sativa Meal Protein Isolates Supplementation on the Physical and Sensory Characteristics of Cookies During Storage. Pakistan Journal of Nutrition, 12 (6): 521-528.

Shafie, M. M., G.A.R. Kamar, A.H.A. Borady and M.M. Hassanein (1984). Reproduction performance of Giza rabbits does under different natural and artificial environmental conditions. Egyptian Journal of Animal Production, 24: 167-174.

Shewita, R.S. and A. E. Taha (2011). Effect of Dietary Supplementation of Different Levels of Black Seed (Nigella Sativa L.) on Growth Performance, Immunological, Hematological and Carcass Parameters of Broiler Chicks. International Journal of Biological, Biomolecular, Agricultural, Food and Biotechnological Engineering, Vol 5, No 5.

Snedcor, G.W. and W.G. Cochran (1982). Statistical Methods $6^{\text {th }}$ Edition Iowa state university press, Ames, U.S.A.

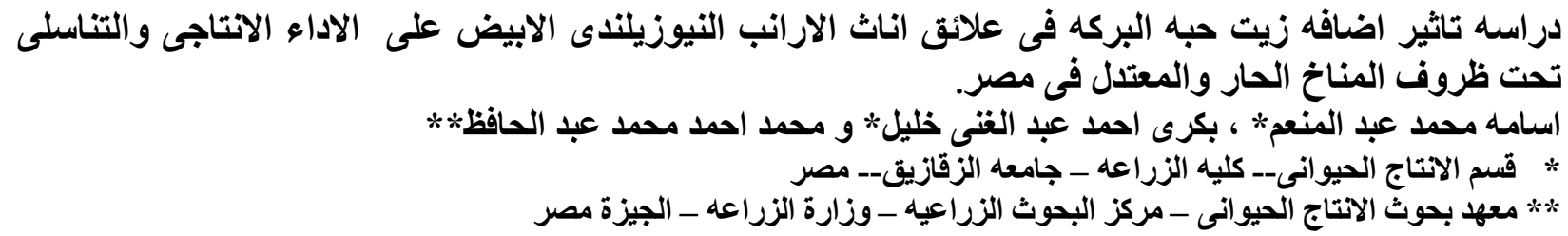

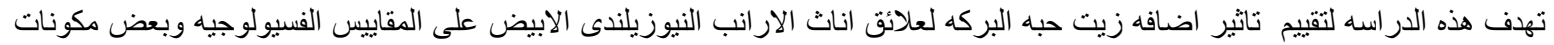

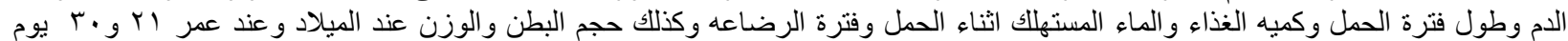

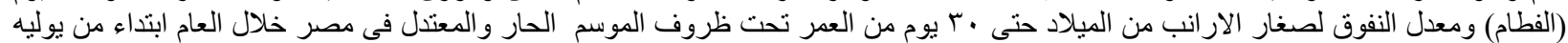
10

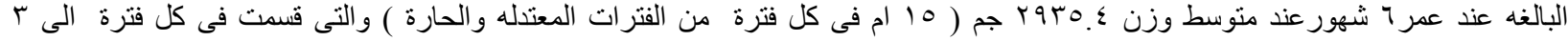

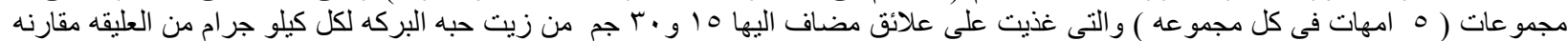

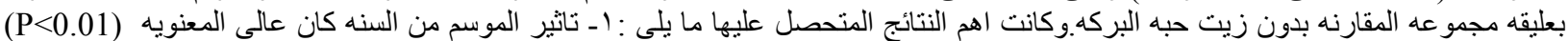

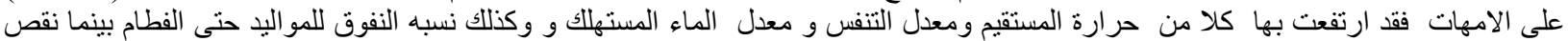

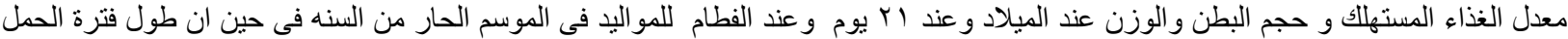

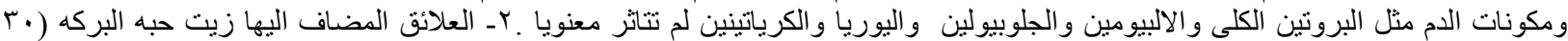

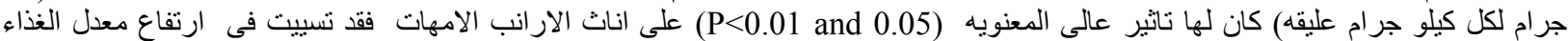

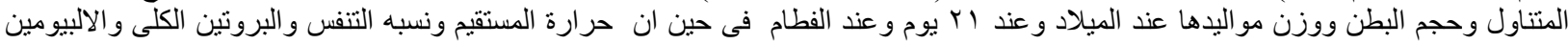

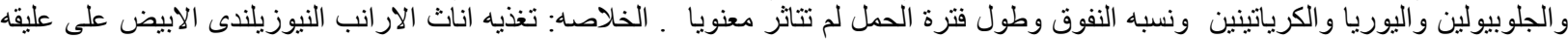

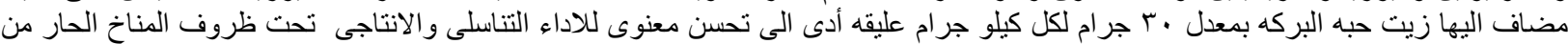

